\title{
Simulation and management implications of feral horse grazing on Cumberland Island, Georgia
}

\author{
MONICA GOIGEL TURNER
}

\begin{abstract}
Cumberland Island National Seashore, Georgia, is inhabited by a population of feral horses that intensively graze the island's salt marshes. Based on 18 months of experimental grazing studies, a carbon flow simulation model was developed for a medium height Spartina alterniflora marsh and used to estimate an acceptable population size of feral horses. Five-year simulations indicated a threshold of $2,700 \mathrm{~kg} / \mathrm{ha}$ aboveground Spartina biomass below which the system did not recover if intensive grazing continued. The difference between this threshold and annual peak biomass of ungrazed Spartina was used to estimate horse densities that would not cause marsh degradation. Results suggest the horse population should number between 49 and 73 horses if excessive damage to the salt marshes is to be prevented. Thus, the current population of 180 horses should be reduced.
\end{abstract}

Key Words: simulation model, salt marsh, Spartina alterniflora, feral horses, Equus caballus population size, Cumberland Island National Seashore

The impacts of exotic species, including feral animals, have been documented in numerous ecosystems (e.g., Bratton 1975, Petrides 1975, Rudge and Campbell 1977, Turner 1984). During the last century, horses (Equus caballus), pigs (Sus scrofa), and cattle (Bos taurus) have ranged free on Cumberland Island National Seashore, Georgia. The U.S. National Park Service removed the cattle in 1974 and has greatly reduced the hog population through trap-

Author is with Environmental Sciences Division, Oak Ridge National Laboratory, Oak Ridge, Tenn. 37831-6038.

This study benefited from many discussions with F.B. Golley, S.P. Bratton, and R.G. Wiegert. The author wishes to thank S.P. Bratton, V.H. Dale, R.H. Gardner, F.B. Golley, and 2 anonymous reviewers for critical comments on the manuscript. Funding was provided by the National Park Service Cooperative Park Studies Unit, Institute of Ecology, University of Georgia. Support for manuscript preparation was provided by the U.S. Department of Energy, Office of Health and Environmental Research, through an Alexander Hollaender Distinguished Postdoctoral Fellowship administered by Oak Ridge Associated Universities, and by Contract No. DE-ACOS840R21400 with Martin Marietta Energy Systems, Inc.

This is publication no. 3156 of the Environmental Sciences Division, Oak Ridge National Laboratory.

Manuscript accepted 8 April 1988. ping. The horse population, however, remains unmanaged and appears to be increasing at a rate of approximately $5 \%$ annually. The population has increased from a minimum of 144 horses in 1981 (Lenarz 1983), to 154 horses in 1983 (Ambrose et al. 1983), and 180 horses in 1985 (Finley 1985).

Feral horses on Cumberland Island feed primarily in salt marshes, dunes, interdune meadows, and lawn areas. Lenarz (1983) reported that $51.7 \%$ of his observations of feral horse feeding occurred in salt marshes, which encompass $34.1 \%$ of the island (Hillestad et al. 1975). Vertebrate herbivory in salt marshes may alter the structure of the vegetation (Chabreck 1968, Shanholtzer 1974), reduce net aboveground primary production (Reimold et al. 1975), reduce standing stocks of belowground biomass (Smith and Odum 1981), result in a network of paths (Howell 1984), or reduce invertebrate populations (Reimold et al. 1975). In mixed species marshes, relative species abundance or successional patterns may be changed (Ranwell 1961, Bakker 1978, 1985, Dijkema 1984). With ungulate grazing, plant regeneration may be slow because of trampling (Chabreck 1968, Jensen 1985).

Horses presently remove up to $98 \%$ of the aboveground standing stock of Spartina alterniflora in heavily grazed marshes on Cumberland Island, and trampling alone can decrease net aboveground primary production (NAPP) by $40 \%$ (Turner 1987 ). Horses may also be having significant impacts on other plant communities on the island (Turner and Bratton 1987). Management of the horse population requires an estimate of the number of horses that can be maintained without excessive damage to natural ecosystems. Based on 18 months of experimental field studies, an ecosystem simulation model of the salt marsh was developed to examine the effects of various grazing intensities on standing stocks of Spartina. The objective was to determine an acceptable population size of horses based on impacts on the salt marsh, their major foraging community. The simulation model and its management implications are described in this paper. 


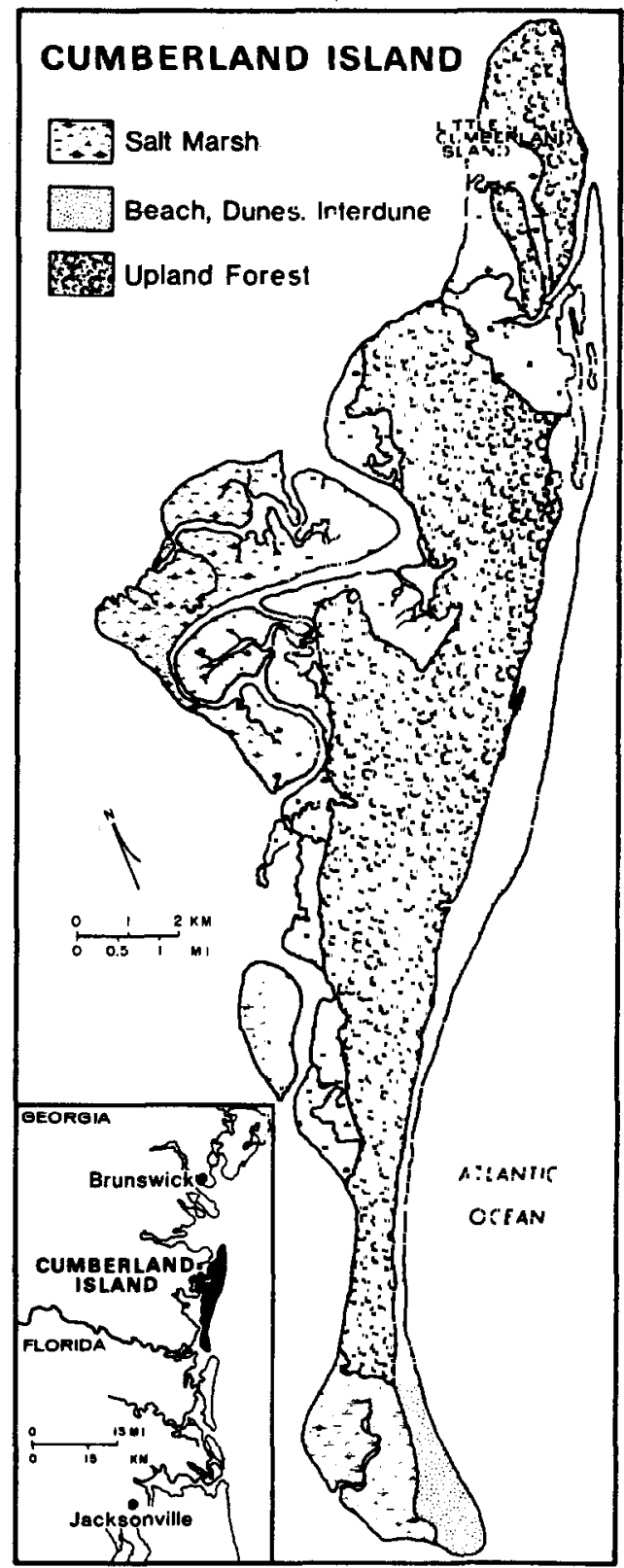

Fig. 1. Map of Cumberland Island, Georgia, showing major vegetation communities.

\section{Study Area}

Cumberland Island, Georgia $\left(30^{\circ} 48^{\prime} \mathrm{N}\right.$. lat., $81^{\circ} 26^{\prime} \mathrm{W}$. long.) is the largest and most southern of the Georgia barrier islands (Fig. 1), measuring $25 \mathrm{~km}$ in length and $9 \mathrm{~km}$ across at its widest point. Designated a National Seashore in 1972, the federal boundaries encompass approximately $14,500 \mathrm{ha}$, owned, and administered by the U.S. National Park Service. The geology, soils, water resources, vegetation, and fauna of Cumberland have been described by Hillestad et al. (1975). The interior of the island is of Pleistocene origin whereas the seaward portion is of the more recent Holocene. Except in dune areas which may reach elevations of $18 \mathrm{~m}$, the island is generally of low relief $(5-8 \mathrm{~m}$ above sea level). The climate is warm temperate to subtropical and is characteristically warm and humid. Major plant communities are those typical for Georgia barrier islands (Johnson et al. 1974). Salt marshes occur throughout the tidal land on the mainland side of the island, characterized by a dominant macrophyte, the smooth cordgrass Spartina alterni- flora. The upper margin of the marsh grades into a grass-forb community composed primarily of glass wort (Salicornia virginica), salt grass (Distichlis spicata), and occasional stands of needle rush (Juncus roemerianus).

The upland portions of the marsh are bounded by tidal creeks that horses do not readily cross. To determine the marsh area accessible to horses, color infrared aerial photographs from 1983 (nominal scale of 1:24,000) and a Bausch and Lomb Zoom Transfer Scope were used. Area was calculated by planimetry. Results indicated that 411 ha of salt marsh were potentially available to the horse population. However, approximately half of this marsh area is only available at mean low tide and is not frequently grazed by horses. The remaining half of the marsh (approximately $205 \mathrm{ha}$ ) is used frequently and is already severely overgrazed (personal observation). The current population of 180 animals (Finley 1985 ) is at a density of 0.88 horse $\cdot \mathrm{ha}^{-1}$ of frequently used salt marsh.

\section{Model Structure}

The model contained 7 compartments (Fig. 2) and was developed to simulate carbon flow through the system on a yearly basis. The objectives of the model were to (1) adequately simulate the ungrazed, or nominal condition, of the salt marsh; (2) simulate current intensities of horse grazing; and (3) predict potential impacts on the marsh due to increased horse grazing.

Table 1. Differential equations used for atate variables in the econystem simulation model.

\begin{tabular}{|c|c|}
\hline Srate yariable & Equation \\
\hline $\mathrm{X}_{1}$, Live aboveground Spartina & $\mathrm{dX}_{1} / \mathrm{dt}=\mathrm{F}_{01}+\mathrm{F}_{31}-\mathrm{F}_{12}-\mathrm{F}_{13}-\mathrm{F}_{14}-\mathrm{F}_{17}-\mathrm{F}_{10}$ \\
\hline $\mathrm{X}_{2}$, Dead aboveground Spartina & $\mathrm{dx}_{2} / \mathrm{dt}=\mathrm{F}_{12}-\mathrm{F}_{20}$ \\
\hline$X_{3}$, Live belowground Spartina & $\mathrm{dX}_{3} / \mathrm{dt} \approx \mathrm{F}_{13}-\mathrm{F}_{36}-\mathrm{F}_{30}-\mathrm{F}_{31}$ \\
\hline$X_{4}$, Insect grazers & $\mathrm{dX}_{4} / \mathrm{dt}=\mathrm{F}_{14}-\mathrm{F}_{40}$ \\
\hline X5, Sediment macroorganic matter & $\mathrm{dX}_{5} / \mathrm{dt}=\mathrm{F}_{65}-\mathrm{F}_{50}$ \\
\hline $\mathbf{X}_{6}$, Aerobic sediment heterotrophs & $d X_{6} / d t=F_{36}-F_{65}-F_{60}$ \\
\hline
\end{tabular}

Nontion $F_{i j}$ indicates a flow of carbon from comparment $i$ to comparuent $j$.

The compartments, or state variables, are related by flows of carbon as shown in Figure 2. Changes in the state variables are calculated by a series of differential equations (Table 1) which incorporate the flows between compartments (Table 2). Season is an important control on many flows, for example, on photosynthesis and respiration. Seasonal variability is included in the model by changing relevant parameters at approximately 90 -day intervals during the simulation. Two types of feedback control are also used in the model: (1) space-related feedbacks, such as overcrowding or self-shading; and (2) resource-related feedbacks, such as resource refuge levels and consumer satiation levels. The general forms of these controls are shown in Table 3, and the functions are fully described by Wiegert (1979). Values of the parameters used in the simulations are listed in Table 4. The computer program was written in BASIC, and calculations in the model are done on a daily basis. Initial conditions were obtained from field data (Tumer 1985, 1987) and are set at the January values at the beginning of each simulation.

Grazing simulations were done for 5 years. The effects of horse grazing on other compartments were simulated, but the population dynamics of the herd (birth rate, death rate, etc.) were not generated internally in the model. Horse density was specified at the beginning of each simulation, either as a constant or with an annual rate of increase. 


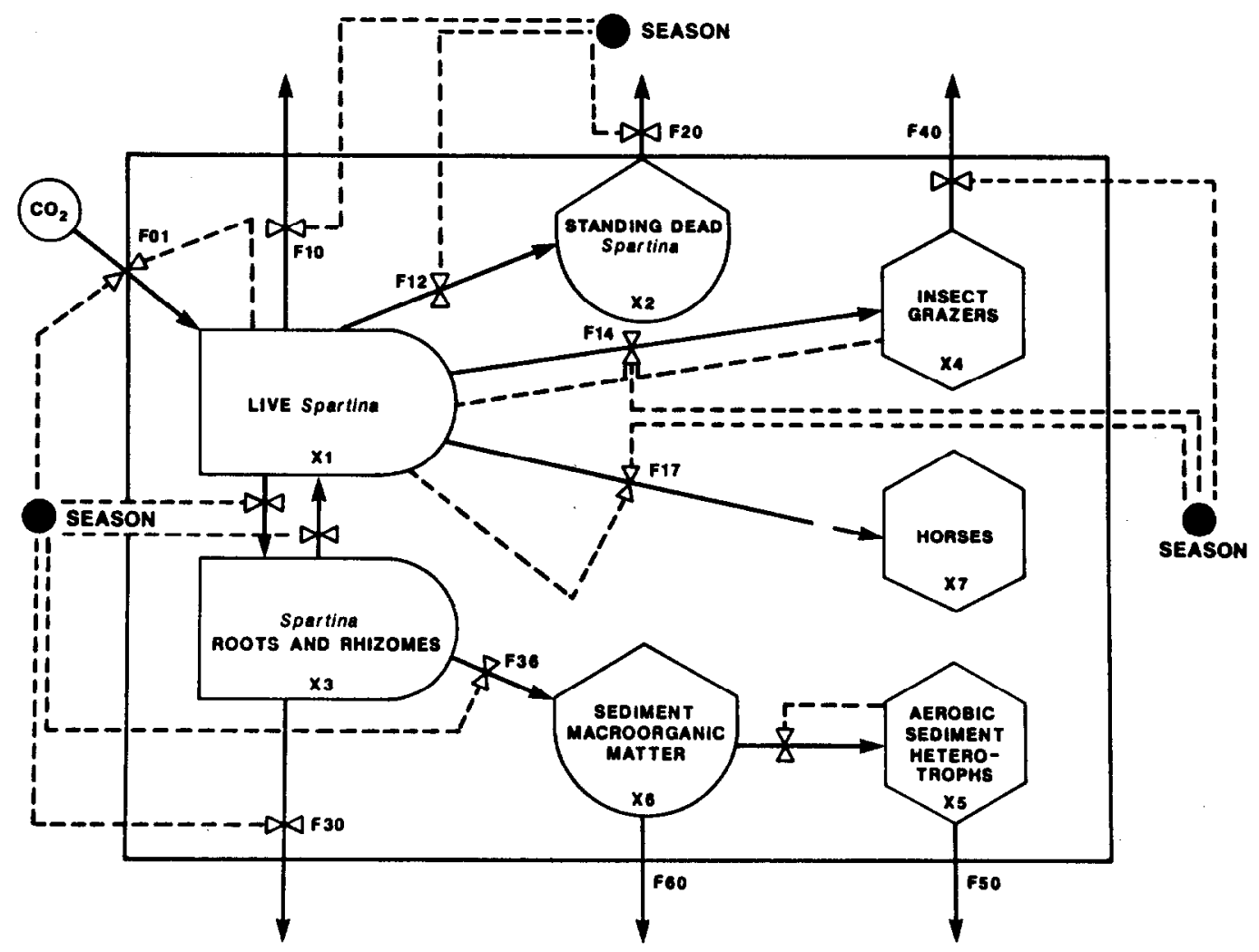

Fig. 2. Diagram of the salt marsh simulation model. Solid lines indicate carbon flow pathways; broken lines are control pathways.

\section{NOMINAL SIMULATION}
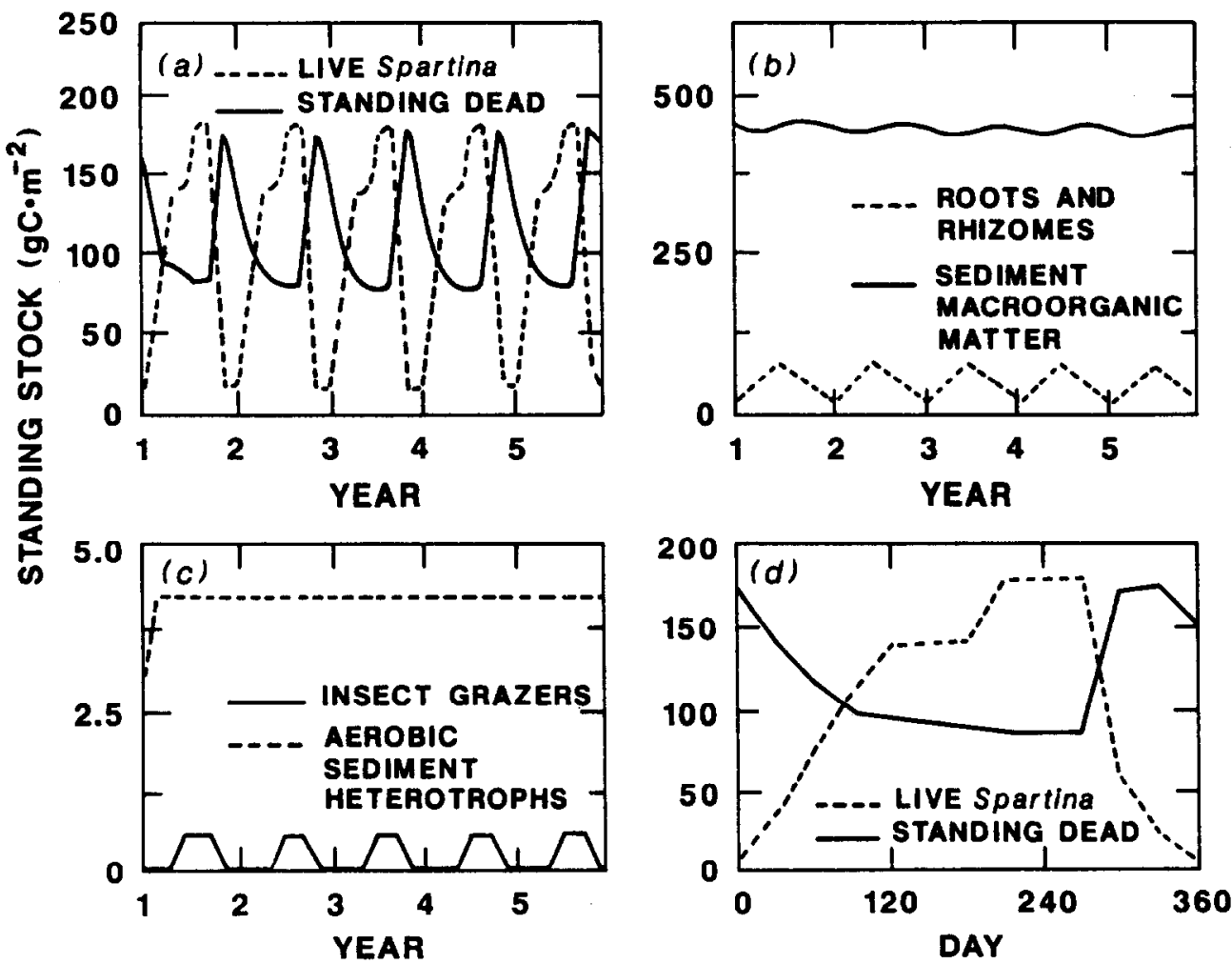

Fig. 3. Simulation of the ungrazed marsh. Figures $3 a, 3 b$, and $3 c$ show dynamics of each compartment in 5 -year simulations. Figure $3 d$ is an expanded view of aboveground Spartina dynamics during 1 year of the simulation, showing seasonal patterns. 
Table 2. Deseription of nows $\left(F_{p j}\right)$ used in the difierential equations.

Fo1 Gross photosynthesis of Spartina [(maximum gross photosynthetic rate by season)(standing stock of Spartina) (space related feedback control with response threshold and carrying capacity)]

F31 Transiocation of carbon from roots to shoots in Spartina [(specific rate of translocation per season)(standing stock of roots and thizomes)]

F10 Respiration of Spartina shoots [ (specific rate of respiration by season)(standing stock of shoots)]

F12 Nonpredatory mortality of Spertina shoots [(death rate of shoots by season)(standing stock of shoots)]

F13 Translocation of carbon from shoots to roots in Spartine [(specific rate of translocation per season)(standing stock of shoots)]

F14 Ingestion of Spartina by insect grazers [(maximum rate of ingestion)(standing stock of insects)(space foedback) (rescurce feedback control with satiation level and refuge level)]

F17 Ingestion of Spartina by horses [(maximum ingestion rate per horse by season)(standing stock of horses) (space feedback)(resource feedback)

F36 Death of live roots and rhizomes, becoming sediment macroorzanic matter [(seasonal death rate)(standing stock of roots and rhizomes)]

F65 Ingestion of macroorganic matter by aerobic heterotrophs [(maximum ingestion rate)(standing stock of hetcrotrophs)(space related feedback term) $(1$-egestion)]

F 60 Loss of macroorganic matter from the marsh, e.g., sinking, tidal export [(specific loss rate)(standing stock of macroorganic matter)]

F40 Respiration of insect grazers [(seasonal specific rate of respiration)(standing stock of insects)]

Fso Respiration of aerobic heterotrophs in the sediment [(seasonal specific rate of respiration)(standing stock of microbes)]

$F_{20}$ Loss of standing dead from the system [(seasonal specific loss rate)(standing stock of standing dead Spartina)]

F30 Respiration and leaching of live Spartina roots and rhizomes [(seasonal specific loss rate)(standing stock of roots and thizomes)]

Table 3. General forms of feedback controls on rates of carbon transfer.

A. Generalized logistic for space-related controls:

$$
f\left(X_{i}\right)=\left[1-(\lambda / \tau)\left\{\left(X_{i}-\alpha_{i j}\right) /\left(K_{j}-\alpha_{i i}\right)\right]\right\}
$$

where

$$
\begin{aligned}
& \lambda=\text { specific loss rate of } X_{i}, \\
& \tau=\text { specific rate of ingestion of } X_{i}, \\
& \alpha_{i i}=\text { density of } X_{i} \text { at which the density response begins, } \\
& \mathbf{K}_{\mathbf{i}}=\text { carrying capacity of } X_{i},
\end{aligned}
$$

such that the function ranges between 0 and 1 , such that when $X_{i}<\alpha_{i i}, f\left(X_{j}\right)=1$ and when $X_{i} \geq K_{i}, f\left(X_{j}\right)=0$; berween these points the function is linear.

B. Generalized resource-related feedbacks:

$$
f\left(X_{i}\right)=\left(1-\left[\left(\gamma_{j}-X_{i}\right) /\left(\gamma_{j}-a_{i j}\right)\right]\right\}
$$

where

$\gamma_{j}=$ the satiation level of resource $X_{i}$ for consumer $X_{j}$ beyond

which the ingestion rate will no longer increase,

$\alpha_{i j}=$ the refuge level of resource $X_{i}$ below which it is not

\begin{tabular}{|c|c|c|c|c|c|}
\hline Parameter & Description & \multicolumn{4}{|c|}{$\begin{array}{c}\text { Value } \\
\text { Winter Spring Summer Fall }\end{array}$} \\
\hline \multicolumn{2}{|r|}{ Specific rates used in now equations } & \multicolumn{4}{|c|}{$\left(\mathrm{day}^{-1}\right)$} \\
\hline TAU01 & maximum photosynthetic rate of Spartina & .062 & .136 & .136 & $.044^{\mathrm{a}}$ \\
\hline TAU13 & $\begin{array}{l}\text { specific rate of translocarion from shoots } \\
\text { to roots }\end{array}$ & .02 & .05 & .01 & $.02^{\mathrm{a}}$ \\
\hline TAU31 & $\begin{array}{l}\text { specific rate of translocation from roots } \\
\text { to shoots }\end{array}$ & .0001 & .003 & .0001 & $.003^{b}$ \\
\hline TAU65 & $\begin{array}{l}\text { maximum ingestion rate of aerobic heter- } \\
\text { otrophs in the sediment }\end{array}$ & .38 & .38 & .38 & $.38 \mathrm{~b}$ \\
\hline TAU14 & $\begin{array}{l}\text { maximuma ingestion rate of insect graxers } \\
\text { on Spartina shoots }\end{array}$ & .25 & .25 & .25 & $.25 \mathrm{c}$ \\
\hline TAU17 & marimum ingestion rate of horses & .0506 & .0482 & .06 & $.0808^{d}$ \\
\hline LAM10 & specific rate of shoot respiration & .0035 & .0048 & .0026 & $.0019 b$ \\
\hline LAM2O & $\begin{array}{l}\text { specific rate of loss of standing dead } \\
\text { from the system }\end{array}$ & .007 & .003 & .024 & $.01^{b}$ \\
\hline LAM30 & $\begin{array}{l}\text { specific rate of respiratory and leaching } \\
\text { losses from roots and thizomes to interstitial water }\end{array}$ & \multicolumn{4}{|c|}{$.00097, .01148, .007653, .01^{b}$} \\
\hline LAM40 & specific rate of insect respiration & .114 & .12 & .12 & $.114^{b}$ \\
\hline LAMSO & $\begin{array}{l}\text { specific loss rate of acrobic heterotrophs } \\
\text { including respiration }\end{array}$ & .11 & .11 & .11 & $.11^{\mathrm{b}}$ \\
\hline LAM60 & $\begin{array}{l}\text { inpecific loss rate of macroorganic matrer } \\
\text { inciuding tidal loss and setuing }\end{array}$ & .0004 & .0004 & .0004 & $.0004^{b}$ \\
\hline MU12 & specific death rate of shoots & .0023 & .0015 & .012 & $.042^{b}$ \\
\hline MU36 & specific death rate of roots and thizomes & .0031 & .0043 & .004 & $.0035 b$ \\
\hline MU56 & specific death rate of enobic heterotrophs & .005 & .005 & .005 & $.00 \mathrm{~s}^{\mathrm{d}}$ \\
\hline \multicolumn{6}{|c|}{ Parameters in control feedback functions $\left(\mathrm{g} C \cdot \mathrm{m}^{-2}\right)$} \\
\hline EPS65 & $\begin{array}{l}\text { proportion of material egested by aerobic } \\
\text { heterotrophs in the sediment }\end{array}$ & \multicolumn{4}{|c|}{.25 (unitless) $^{d}$} \\
\hline Al.PHA11 & threshold response density of shoots & \multicolumn{4}{|c|}{$10 \mathrm{~d}$} \\
\hline ALPHA44 & threshold response density of insect grazers & \multicolumn{4}{|c|}{$1.25 \mathrm{e}$} \\
\hline ALPHASS & threshold response density of aerobic heterotrophs & \multicolumn{4}{|c|}{$7.44^{\mathrm{a}}$} \\
\hline $\mathbf{K} \mathbf{1}$ & carrying capacity of shoots & \multicolumn{4}{|c|}{$200 \mathrm{~d}$} \\
\hline K4 & carrying capacity of insect grazers & \multicolumn{4}{|c|}{$1.25 \mathrm{e}$} \\
\hline $\mathbf{K 5}$ & carrying capacity of aerobic heterotrophs & \multicolumn{4}{|c|}{$9.0^{b}$} \\
\hline ALPHA17 & refuge level of shoots from horse grazing & \multicolumn{4}{|c|}{$7.26^{\mathrm{d}}$} \\
\hline GAMMAI7 & satiation level of shoots with regand to horses & \multicolumn{4}{|c|}{$40 d$} \\
\hline
\end{tabular}
available to consumer $\mathbf{X}_{j}$

such that the function ranges from 0 to 1 , such that when $X_{i}<\alpha_{i j}$, then $f\left(X_{i}\right)=0$ and consumption by $X j$ will also be 0 , and when $X_{i} \geq \gamma_{j j}$ then $f\left(X_{i}\right)=1$ and consumption by $X_{j}$ will be at a maximum; between $\alpha$ and $\gamma$, the function is linear.
Table 4. Values of parameters used in the simulation model.

Modified from Wiegert and Wetzel (1979) using data from Turner $(1985,1987)$.

brom Wiegen and Werzel (1979).

cFrom Smalley (1959).

dFrom Turner (1985, 1987)

CFrom Wiegert et al. (1975).

\section{Results}

\section{Simulations}

The nominal model simulates stable annual cycles of the components and shows no net change from year to year (Fig. 3). Seasonal growth cycles are apparent; peak biomass is reached in late summer, while peak standing dead occurs in early winter. Insect grazers increase during the summer, then decline. These simulations agree closely with field data from horse exclosures (Turner 1987), as illustrated by comparing an annual cycle of simulated and observed ungrazed live Spartina alterniflora biomass (Fig. 4). A series of sensitivity analyses was also done with the nominal model (see Turner 1985), indicating as expected that Spartina productivity was the dominant control in the marsh.

The effects of grazing on Spartina standing stocks with constant horse densities are shown in Figure 5a-c. With 0.136 horse/ha, Spartina productivity is sustained (Fig. 5a). When the horse den- 
sity increases to 0.151 horse / ha, standing stocks decline gradually during the 5-year simulation (Fig $5 b$ ); and a density of 0.165 horse/ ha causes a drastic reduction in Spartina biomass (Fig. 5c). Horse grazing also caused macroorganic matter to be lost from the system during the simulations, but the insect grazer and bacterial populations were not affected. Results of simulating the horse population using the current annual rate of increase, 0.05 , and beginning with a density of 0.136 horse/ha are shown in Fig. $5 d$. This simulation suggests a sharp demarcation between what appear to be tolerable intensities of grazing and deleterious levels. When the aboveground peak biomass of Spartina falls below a threshold of about $125 \mathrm{~g} \mathrm{Com}^{-2}$ (equivalent to $2,700 \mathrm{~kg}^{-1} \mathrm{ha}^{-1} \mathrm{dry}$ weight of Spartina), the plants cannot recover unless grazing intensity is reduced. This occurs because primary productivity becomes insufficient to support the herbivory, and Spartina standing stocks fall to refuge levels; when grazing pressure is reduced, biomass will again increase.

Actual grazing patterns on the marsh vary spatially, with some areas used intensively and other areas only used sporadically. The grazing simulations correspond closely with field data from plots which had light, moderate, and high intensities of horse grazing (Fig. 6). The model generates reasonable effects of grazing, as can be seen by comparing the curves in Figure 6 with 1-year segments of the grazing simulations shown in Figure 5.

\section{Estimating an Acceptable Horse Population Size}

Biomass produced in excess of the threshold of $2,700 \mathrm{~kg}^{\circ} \mathrm{ha}^{-1}$ was considered a sustainable loss of Spartina to horse grazing. A range for the size of the horse population was then determined. This required several steps:

1. Average daily consumption of forage per horse (Table 5) was estimated at $7.7 \mathrm{~kg}$ dry weight per day based on standard horse nutritional requirements (National Research Council 1978) and

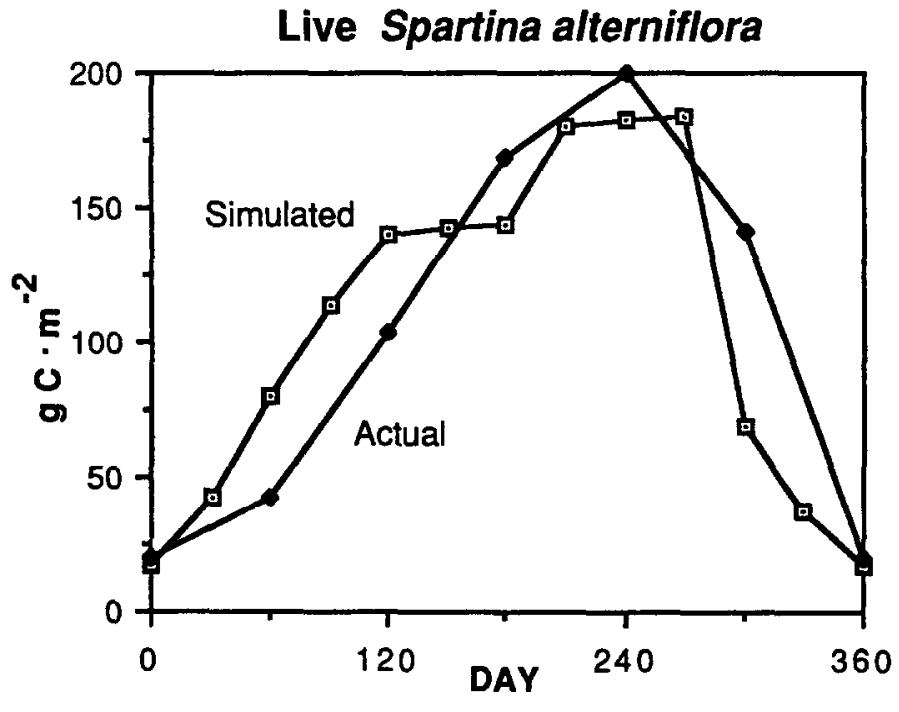

Fiz. 4. Comparison of one-year simulation of live Spartina and 1984 field data (from Turner 1985, 1987).

the population structure of the herd in 1983. This value will vary with herd structure.

2. Average daily consumption of Spartina per horse was estimated to be $50 \%$ of total forage, based on Lenarz's (1983) observations of horse foraging. A higher $(60 \%)$ and lower $(40 \%)$ proportion of Spartina in the diet was also examined to bracket the estimates with more and less intense grazing effects. Thus, annual Spartina consumption per horse is:

$0.60 \times 7.7 \mathrm{~kg} \times 365$ days $=1,686 \mathrm{~kg} /$ year (more intense grazing)

\section{GRAZING SIMULATIONS}

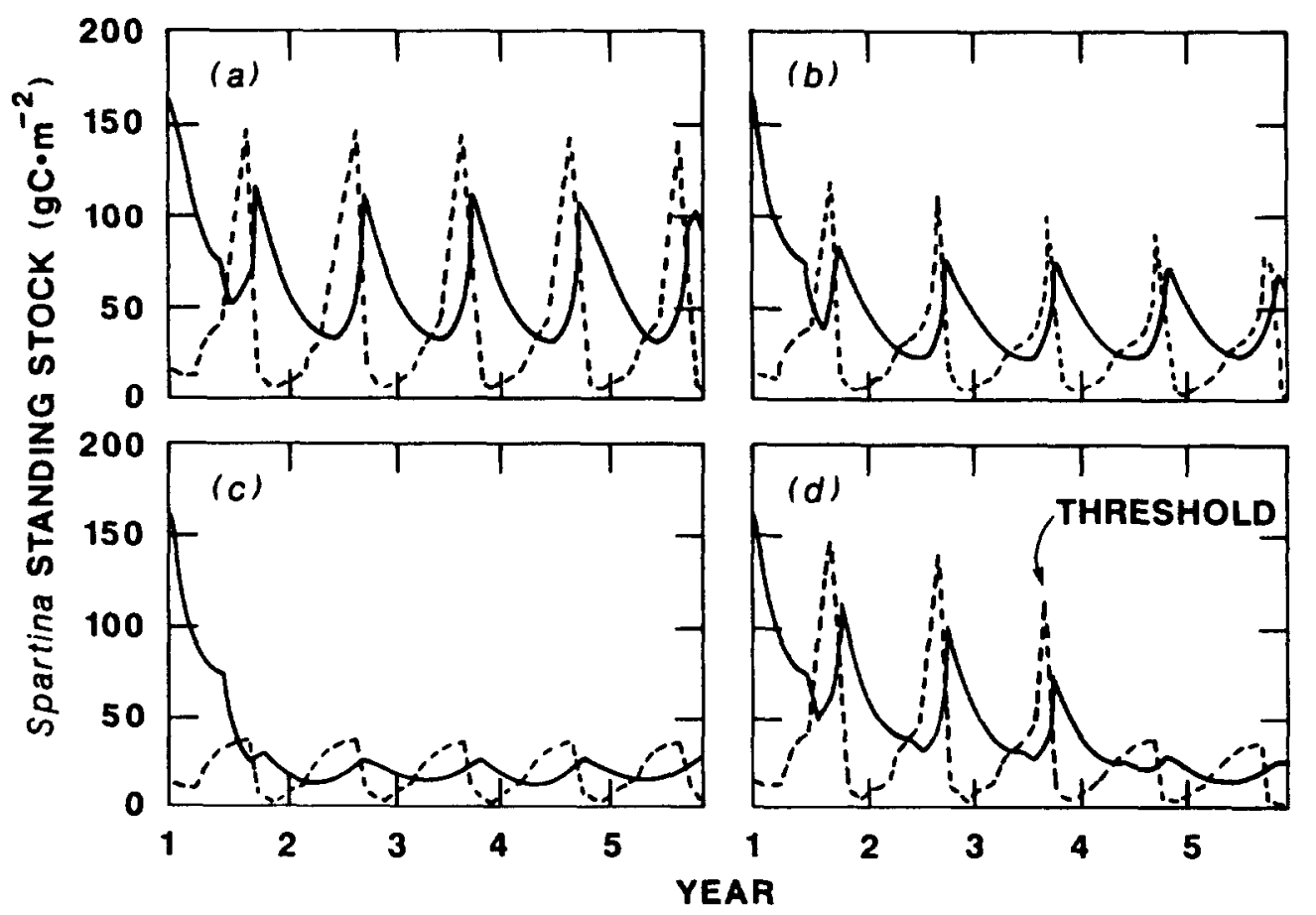

Fig. S. Simulated aboveground Spartina with different horse grazing intensities: (a) 0.136 horse/ha; (b) 0.151 horse/ha; (c) 0.165 horse/ha; (d) 0.136 horse/ha increasing at 5\% per year. Note threshold level in (d) where decline in Spartina standing stock is quite sharp. 
Table 5. Daily forage requirements per hore for the 1984 feral horse population on Cumberland laland.

\begin{tabular}{lcccc}
\hline \hline Class & $\begin{array}{c}\text { Number of } \\
\text { Horses }\end{array}$ & $\begin{array}{c}\text { Digestible energy } \\
\text { required per horseb,c } \\
(\mathrm{Mcal})\end{array}$ & $\begin{array}{c}\text { Dry forage } \\
\text { required per horse b,d } \\
(\mathrm{kg})\end{array}$ & $\begin{array}{c}\text { Total dry forage } \\
\text { required } \\
(\mathrm{kg})\end{array}$ \\
\hline Mature horses & 113 & 16.86 & 7.7 & 870.1 \\
Lactating mares & 7 & 25.00 & 11.4 & 79.8 \\
Foals & 7 & 9.10 & 4.1 & 28.7 \\
Yearlings & 27 & 16.80 & 7.6 & 205.2 \\
TOTAL & 154 & - & - & 1183.8 \\
Average & - & - & 7.7 & -
\end{tabular}

From Ambrose et al. 1983.

Data source: National Research Council (1978).

CBased on $400 \mathrm{~kg}$ manre weight, includes maintenance requirement plus $3 \mathrm{Mal}$ for walking

dBased on vilues reponted for digestible energy content of grazed grasses.

Estimated from the number of foals.

$0.50 \times 7.7 \mathrm{~kg} \times 365$ days $=1,405 \mathrm{~kg} /$ year (average grazing)

$0.40 \times 7.7 \mathrm{~kg} \times 365$ days $=1,124 \mathrm{~kg} /$ year (less intense grazing)

3. From the model and field data, the amount of Spartina available to the horses if the integrity of the marsh is to be maintained was estimated at $400 \mathrm{~kg} / \mathrm{ha}$. This number was estimated as follows. Field data indicated a range of annual net aboveground primary production from 3,000 to $4,250 \mathrm{~kg} /$ ha (Turner 1987 ). The simulation model indicated a threshold level of $2,700 \mathrm{~kg} / \mathrm{ha}$ of Spartina, below which the system could not be sustained if grazing continued at the same intensity. This suggests that a yearly loss to grazing of 300 to $1,550 \mathrm{~kg} /$ ha might be tolerable, depending on location; thus a loss of $800 \mathrm{~kg} / \mathrm{ha}$ might be acceptable on average. But, because trampling causes a decrease in NAPP equivalent to that of consumption (Turner 1987), only half the $800 \mathrm{~kg} / \mathrm{ha}$ should actually be consumed as forage.

4. The area of marsh required per horse could then be determined: $1,686 \mathrm{~kg} / \mathrm{horse} / 400 \mathrm{~kg} / \mathrm{ha}=4.2 \mathrm{ha} / \mathrm{horse}$ (more intense grazing) $1,405 \mathrm{~kg} / \mathrm{horse} / 400 \mathrm{~kg} / \mathrm{ha}=3.5 \mathrm{ha} /$ horse (average grazing)

$1,124 \mathrm{~kg} /$ horse $/ 400=2.8 \mathrm{ha} /$ horse (less intense grazing)

5. The final step then requires dividing the generally accessible marsh area (205) ha by the area required per horse:

$205 \mathrm{ha} / \mathbf{4} .2 \mathrm{ha} /$ horse $=\mathbf{4 9}$ (more intense grazing)

$205 \mathrm{ha} / 3.5 \mathrm{ha} /$ horse $=59$ horses (average grazing)

$205 \mathrm{ha} / 2.8 \mathrm{ha} /$ horse $=73$ horses (less intense grazing)

Thus, an acceptable range for the size of the horse population may be between 49 and 73 animals, which is $27 \%$ to $40 \%$ of the current population size.

\section{Discussion}

Because of the numerous potential impacts of horse grazing on Cumberland Island, the population estimates derived in this paper are probably conservative. For example, implications of horse grazing for the marsh extend beyond a reduction of Spartina biomass. Because accretion of sediment in marshes is a function of the density of grasses present to trap particles (Gleason et al. 1979), heavily grazed marshes may be more susceptible to erosion and storm damage. Thus, intensive grazing could create conditions that favor the loss of marsh habitat. Species distributions on the marsh may also be altered by heavy grazing, permitting Salicornia spp., which is unpalatable to horses, to dominate (Reimold et al. 1975). Grazing may reduce populations of fiddler crabs (Reimold et al. 1975) which are known to exert a positive influence on Spartina growth (Montague 1980) and are prey for consumers such as raccoons. Intense grazing by horses may also alter the detrital food web, indirectly affect other consumer populations, or change the export/import of organic matter from the marsh.

Effects on other island habitats were not considered in the
Live Spartina alterniflora

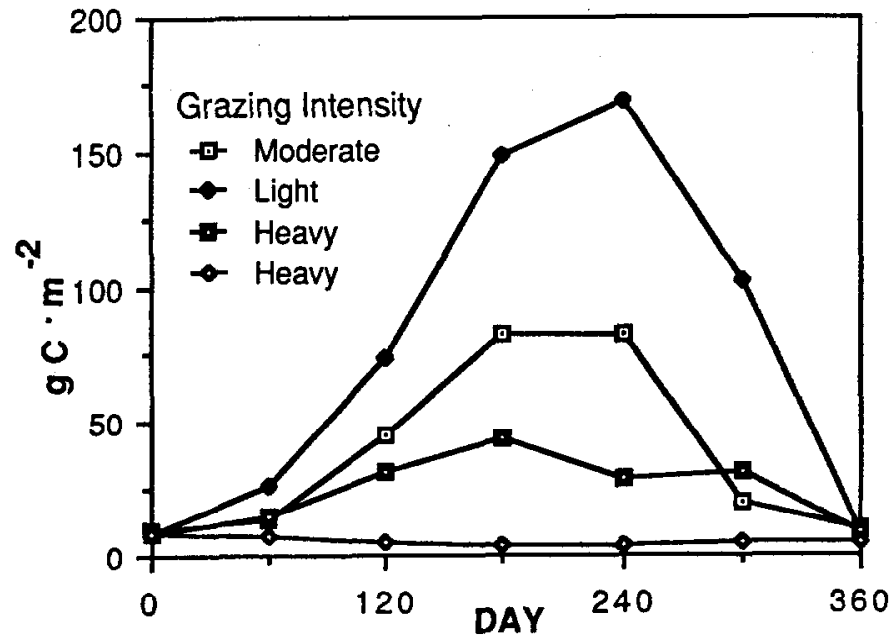

Fig. 6. Aboveground live Spartina in 1984 with different intensities of horse grazing (data are from Turner 1985, 1987). These curves can be compared with one-year segments of the simulations shown in Figure 5.

model. Impacts of the horses on communities such as the interdune meadow and maritime forest should be monitored. For example, the model assumes a constant proportion of Spartina in the horses' diet and that switching to a different forage does not occur. As the marsh becomes more severely overgrazed, horses may select an alternative food source, which may increase their impact on other habitats.

The horse population has significance in the history of Cumberland Island, and there is public interest in maintaining the herd. This study suggests that a small horse population can probably be maintained on Cumberland Island without excessive marsh deterioration. The population must be reduced from its present size, however, to permit recovery of the overgrazed marshes. This study indicates an acceptable population of 49 to 73 animals on the island based on current grazing intensities in the marshes. A smaller horse population could also be restricted to a portion of the island and excluded from the remainder, permitting a recovery from grazing. The long-term impacts of horse grazing on the marshes and other habitats should also be monitored regularly.

\section{Literature Cited}

Ambrose, J., S. Bratton, K. Davison, L. Fitch, M. Goigel, F. Golley, F. Lemis, J. McMurtray, W. Querin, and D. Simon. 1983. An analysis of feral horse population structure on Cumberland Island. National Park Service CPSU Tech. Rep. No. 1. Institute of Ecology, University of Georgia, Athens.

Bakker, J.P. 1978. Changes in salt marsh vegetation as a result of grazing and mowing: A 5-year study of permanent plots. Vegetatio 38:77-88.

Bakker, J.P. 1985. The impact of grazing on plant communities, plant populations and soil conditions on salt marshes. Vegetatio 62:391-398.

Bratton, S.P. 1975. The effect of the European wild boar (Sus scrofa) on Gray Beech Forest in the Great Smoky Mountain National Park. Ecology 56:1356-1366.

Chabreck, R.H. 1968. The relation of cattle and cattle grazing to marsh wildlife and plants in Louisiana. Proc. Annu. Conf. Southeast Assoc. Game Fish Comm. 22:55-58.

Dijekma, K.S. (ed). 1984. Salt marshes in Europe. Counc. of Europe, Publications Section, Strasbourg.

Finley, M. 1985. Structure of the feral horse population, 1985: Cumberland Island National Seashore. National Park Service CPSU Tech. Rep. No. 17. Institute of Ecology, University of Georgia, Athens.

Gleason, M.L., D.A. Elmer, N.C. Pien, and J.S. Fishor. 1979. Effects of stem density upon sediment retention by salt marsh cord grass, Spartina alterniflora Loisel. Estuaries 24:271-273. 
Hilleatad, H.O., J.R. Bozeman, A.S. Johneon, C.W. Beriaford, and J.L. Richardson. 1975. The ecology of Cumberland Island National Seashore, Camden County, Georgia. U.S. Nat. Park Serv., Tech Rep. Series 75-5.

Howel, P.T. 1984. Use of salt marshes by meadow voles. Estuaries 7:165-170.

Jensen, A. 1985. The effect of cattle and sheep grazing on salt marsh vegetation at Skallingen, Denmark. Vegetatio 60:37-48.

Johnaon, A.S., H.O. Hillestad, S.F. Shanholtzer, and G.F. Shanholtzer. 1974. An ecological survey of the coastal region of Georgia. Nat. Park Serv. Monogr. Ser. 3.

Lennrz, M.S. 1983. Population size, movements, habitat preferences, and diet of the feral horses of Cumberland Island National Seashore. Nat. Park Serv. CPSU Tech. Rep. 3. Institute of Ecology, Univ. Georgia, Athens.

Montague, C.L. 1980. The net influence of the mud fiddler crab, Uca pugnax, on carbon flow through a Georgia salt marsh: the importance of work by macroorganisms to the metabolism of ecosystems. Diss., Univ. Georgia, Athens.

National Research Council. 1978. Nutrient requirements of horses. Nat Acad. Sci., Washington, D.C.

Petrides, G.A. 1975. The importation of wild ungulates into Latin America, with remarks on their environmental effects. Environ. Conserv. 2:47-51.

Ranwell, D.S. 1961. Spartina marshes in southern England. I. The effects of sheep at the upper limits of Spartina marsh in Bridgewater Bay. J. Ecol. 49:325-340.

Reimold, R.J., R.A. Linthurst, and P.L. Wook. 1975. Effects of grazing on a salt marsh. Biol. Conserv. 8:105-125.

Rudge, M.R., and D.J. Campbell. 1977. The history and present status of goats on the Auckland Islands in relation to vegetation changes induced by man. New Zeal. J. Bot. 15:221-253.
Shanholtzer, G.F. 1974. Relationships of vertebrates to salt marsh plants. P. 463-474. In: R.J. Reimold and W.H. Queen (eds.), Ecology of Halophytes. Academic Press, New York.

Smalley, A.E. 1959. The role of 2 invertebrate populations, Littorina irrorata and Orchelimum fidicinium, in the energy flow of a salt marsh ecosystem. Diss. Univ. Georgia, Athens.

Smith, T.J., III, and W.E. Odum. 1981. The effects of grazing by snow geese on coastal salt marshes. Ecology 62:98-106.

Turner, M.G. 1984. Habitat utilization by burros in Virgin Islands National Park. J. Wildl. Manage. 48:1461-1464.

Turner, M.G. 1985. Ecological effects of multiple perturbations on a Georgia salt marsh. Diss. Univ. Georgia, Athens.

Turner, M.G. 1987. Effects of grazing by feral horses, clipping, trampling, and burning on a Georgia salt marsh. Estuaries 10:56-62.

Turner, M.G., and S.P. Bratton. 1987. Fire, grazing and the landscape heterogeneity of a Georgia barrier island. P. 85-101. In: M.G. Turner (ed.), Landscape Heterogeneity and Disturbance. Springer-Verlag, New York.

Wietert, R.G. 1979. Population models: experimental tools for the analysis of ecosystems. P. 233-274. In: D.J. Horn, G.R. Stairs and R.D. Mitchell, eds. Analysis of ecological systems . Ohio State Univ. Press, Columbus.

Wiegert, R.G., R.R. Chriatian, J.L. Gallagher, J.R. Hall, R.D.H. Jones, and R.L. Wetzel. 1975. A preliminary ecosystem model of coastal Georgia Spartina marsh. P. 583-601. In: L.E. Cronin (ed.), Estuarine Research, Vol. I. Academic Press, New York.

Wiezert, R.G., and R.L. Wetzel. 1979. Simulation experiments with a fourteen-compartment model of a Spartina salt marsh. P. 7-35. In: R.F. Dame (ed.), Marsh-estuarine systems simulation. Univ. South Carolina Press, Columbia. 